\title{
Alignment of Belt and Road Initiative with Africa Agenda 2063
}

\author{
Honglie Zhang* \\ International Business School \\ Yunnan University of Finance and Economics \\ Kunming, China \\ yufehelen@126.com
}

\author{
Tesfaye Niway \\ International Business School \\ Yunnan University of Finance and Economics \\ Kunming, China \\ tiffanymulsa@yahoo.com
}

\begin{abstract}
The Chinese state to strategically lead and solve the problems related with unemployment, unbalanced economic development of people of more than 1.4 billion, it has formulated 3 [1] major strategies, and among which Belt and Road Initiative (hereinafter called BRI) is the one. Africa, through its continental organization, AU, has formulated agenda 2063 in which it stipulates the aspirations of African and its implementation mechanisms for the next 40-50 years, which includes integrating African by solving infrastructure deficit. As BRI has embraced Africa as partner and agenda 2063 takes integration agenda as the means and result for the African renaissance there are some common elements between these two grand projects/initiatives.
\end{abstract}

This research deals on questions: what are the main components of BRI and Agenda 2063? What are the institutional mechanisms to coordinate the plans? What has been done to coordinate till now? What needs to be done to coordinate them further and enhance the result of the plans? The researchers has concluded that though there are a lot of common objectives that the two plan want to achieve, what has been performed till now is not enough. Hence, the researchers have recommended some of the activities that need to be done to realize the objectives of the plans fully.

Keywords - belt and road initiative; agenda 2063, infrastructure deficit

\section{INTRODUCTION}

Africa and China have an established long history of trade, exchange, and friendship [2].Through the Silk Road, the valley of the Nile has been used as the route [2]. The east Africa is recalled as the westernmost stop on Admiral Zheng He's spectacular voyages [3]. The relationship has been intercepted for many centuries and it has been re-started again with the foundation of People Republic of China by the Communist Party of China in 1949. Then after with the Bandung conference, 1956, and the coming of non-aligned movement, the diplomatic relations between Africa and China cemented in a new way [4].

After the opening up and reform policy, the Chinese government has set foreign relation principles with Africa in 1983; equality and mutual benefit, pursuing practical results, adopting various paths and seeking common development[4].
In the second millennium, in order to cement the relationship between Africa and China, China created the forum on China -Africa Cooperation (FOCAC). On its inaugural meeting, the forum has promulgated and adopted the Beijing Declaration of the Forum on China-Africa Cooperation and Programme for China-Africa Cooperation in Economic and Social Development. The second conference was conducted in Ethiopia, in December 2003, and come up with Addis Ababa Action Plan (2004-06).

Chinese, for the reasons that will be explained in this research, has devised Belt and Road Initiative (BRI) which also includes African continent as a partner. Africa also has devised agenda 2063 in which it articulated African people's aspirations and streamline the relationship with partners, which includes China. On this research, the researchers analyze the main content and alignment of each plans, spot the progress of implementation, how they were aligned and ways to align further.

\section{AIMS BRI, FINANCING INSTITUTIONS AND PARTIES TO THE INITIATIVE}

The Chinese state as the initiator and propeller of the initiative [5] has published a document called Vision and Actions on Jointly Building Silk Road Economic Belt And 21st-Century Maritime Silk Road, lays out the basic aims of the Belt and Road Initiative. The following are some of the aims and performance of the same.

\section{A. Markets Integration}

The action plan has put some measures to be taken on areas like custom, information exchange, standards, law enforcement, tariff issues, trade on agricultural products, energy, information technology, open service industry and sustainable environment, corporate social responsibility as some of the areas need to be reformed to realize this aim.

After the declaration of the initiative the total trade between China and other belt and road countries in 2014-2016 exceeded USD 3 trillion worth and China's investment in belt and road countries has surpassed USD 50 billion [5].

\footnotetext{
*Corresponding author
} 


\section{POLICY CO-ORDINATION}

Policy coordination has been taken both as an aim and priority area by the action plan. Policy coordination is expected to exist on areas of macro policy, economic development strategies policies and plans and large-scale projects.

Within the last four year regarding to policy coordination Eurasian economic Union, Masterplan on Connectivity by the ASEAN, the bright road initiative in Kazakhstan, the Middle corridor initiative in Turkey, the Development road initiative in Mongolia, the two corridors, One economic initiative corridor by Vietnam, the Northern powerhouse initiative by UK and the Amber Road initiative by Poland, as examples of leaps done in this area [5].

\section{CONNECTIVITY}

Connectivity expected to exist on areas of infrastructure construction plans and technical standard systems, construction of international trunk passageways, green and low-carbon infrastructure construction and operation management, construction focus on the key passageways, junctions and projects, and linking up unconnected road sections, road safety facilities and traffic management facilities and equipment, and road network, whole-course transportation, customs clearance, reloading and multimodal transport, and port infrastructure construction, land-water transportation channels, and sea routes and the number of voyages, information technology cooperation in maritime logistics, expand and build platforms, civil aviation, energy infrastructure, cross border optical cables and other areas.

On implementation of this aim Jakarta-Bandung highspeed railway, China -Lao railway, Addis Ababa Djibouti railway, Hungary Serbia railway and Gwadar and Piraeus ports have been the cited one. There are also other projects in the pipeline which includes China-Pakistan Economic Corridor, China-Mongolia-Russia Economic Corridor, and New Eurasian Continental Bridge [5].

\section{PeOPle to PeOPle Bond}

The Chinese state considers the ancient Silk Road as a route of friendship, peace, and cooperation, openness and inclusiveness, mutual learning and benefit, then a route of trade, the Silk Road spirit [5]. Based on this, the initiative has clearly stated that the people to people bond is an important element or integral part [5] for the implementation of the initiative. This people to people bond will be realized on areas cultural, academic, media cooperation, information, education, tourism and sport, medical assistance, technology transfer, political parties and parliaments, cities, and non-governmental organizations.

For the last four years through educational Silk Road and health Silk Road, the Chinese government is providing each year 10,000 government scholarship.

\section{FINANCING INSTITUTIONS}

As the initiative is the brainchild of the Chinese state, it is working tirelessly to realize the initiative. China is backing the plan with great amount of resources: $\$ 1$ trillion in "government money" would be spent on the initiative, according to various sources [6]. Reports said that the China Development Bank would spend $\$ 900$ billion on over 1000 projects involving those countries along the BRI route to support the initiative [6].

The Chinese government along other BRI countries has devised the following institutional mechanisms to implement the initiative. First, President Xi, on November 8/ 2014, announced that China will contribute 40 billion U.S. dollars to set up the Silk Road Fund. During the Beijing APEC meetings, $\mathrm{Xi}$ announced that the fund will be used to provide investment and financing support to countries along the belt and road for connectivity projects such as infrastructure, resource development, industrial cooperation, financial cooperation [5]. The Fund has been officially established on December 29/2014 as Silk Road Fund Co., Ltd. In addition to this, the Chinese government pledged to contribute additional USD 100 billion for the fund [5].

Second President $\mathrm{Xi}$ In his speech at the Indonesian parliament, proposed of establishing the Asian Infrastructure Investment Bank (AIIB) to finance infrastructure construction and promote regional inter-connectivity and economic integration. Fifty-seven countries have joined AIIB as founding members and signed the Memorandum of Understanding on Establishing AIIB and the Bank has been duly established in 2015. Now the Bank has 84 approved members [7]. Madagascar, South Africa, and South Sudan are prospective members of the Bank [6]. Within the last four years, the bank has provided USD 1.7 billion in loans for nine projects in participating countries [6].

Third, In July 2014, China and its partners in the so-called BRICS bloc-Brazil, Russia, India, China and South Africa contributed 100 billion USD with having equal voting power establish the New Development Bank [7].

\section{PARTIES TO THE INITIATIVE}

The initiative has been planned to connect more than 65 countries with a combined population of 4.5 billion and interacts with economies representing $40 \%$ of world GDP and USD 21 trillion economic aggregation [3]. To date, more than 100 countries and international organizations have joined the initiative [5]. Xi Jinping says that the initiative is open to all countries from all five continents, Asia, Europe, Africa, North America and South America [5]. Hence, all countries and economies and international and regional organizations with intention could join us and become a supporter, builder and beneficiary of "one belt and one road" [5].

A Chinese report [8] released by the China International Trade Institute in August 2015 identified 65 countries along the belt and road initiative. From this data, from Africa, only Egypt has been considered as part of the initiative. But this does not mean that other African countries do not show an interest in the initiative. This could be analyzed in detail in the following part.

By the end of September 2017, China has signed 74 cooperation agreements related with the BRI with countries and international organizations [5]. 
VIII. The Alignment of AFricAn Union AgENDA 2063 AND BRI

\section{A. Agenda 2063}

African Union has devised a long-term blueprint for development and growth in Africa called Agenda 2063 which is rooted in Pan Africans and Africa Renaissance. The agenda provides a robust framework for addressing past injustices and the realization of the 21 st Century as the African Century. It is a strategic framework for the socio-economic transformation of African Continent over the next 50 years [9].

Agenda 2063 has listed down the 7 aspirations for the continent. Which includes "A prosperous Africa based on inclusive growth and sustainable development, An integrated continent, politically united based on the ideals of PanAfricanism and the vision of Africa's Renaissance, An Africa of good governance, democracy, respect for human rights, justice and the rule of law, A peaceful and secure Africa, An Africa with a strong cultural identity, common heritage, values and ethics, An Africa, whose development is people-driven, relying on the potential of African people, especially its women and youth, and caring for children, Africa as a strong, united, resilient and influential global player and partner.'[9]

Among those seven aspirations, the following are inextricably linked with the infrastructure deficit and African renaissance and somehow that could be directly aligned with the BRI. Aspiration no 2 says an integrated continent, politically united based on the ideals of Pan Africanism and the vision of African renaissance. The document defined this aspiration in lieu of having "a united Africa, having a worldclass, integrative infrastructure that crisscrosses the continent. It also says by 2063 the necessary infrastructure will be in place to support Africa's accelerated integration and growth, technological transformation, trade, and development. This will include high-speed railway networks, roads, shipping lines, sea and air transport as well as well developed ICT and the digital economy. A Pan-African high-speed train network will connect all the major cities/capitals of the continent with adjacent highways and pipelines for gas, oil, water as well as ICT broadband cables and other infrastructure. This will be a catalyst for manufacturing skill development technology, research, and development, integration and intra-African trade, investment and tourism" [9].

\section{AFricAn Institutions UsED to ALIGN AGENDA 2063 WITH BRI}

There are different institutions which could use as platform to align agenda 2063 and BRI. First, Africa and China has established The China-Africa Cooperation Forum which serves as a consultation, cooperation platform. The forum on the one hand it enhances cooperation an consultation between Africa and China and on the other hand seeking mutual reinforcement and cooperation [10]. AU has been taken as the full member of FOCAC in 2011, which in effect every declaration and deliberation made in the name of FOCAC will be the property of AU.

The second platform is Programme for Infrastructure Development in Africa (PIDA).The Programme for
Infrastructure Development in Africa (PIDA) is a continental initiative recognized by African Head of states that anchored to solve infrastructure deficit by listing priorities and looking for the financing options [10].

The initiative is looking for the support of other countries, particularly China, on the financing of the projects.

\section{A. The Alignment between Agenda 2063 and BRI}

From the previous analysis, it is possible to identify the following points as a conclusion. Both African countries and China are developing countries have somehow similar challenges and needs similar solutions. To solve similar challenges and come up with workable and informed decisions they need to continue the consultation, dialogue, cement the multifarious nature of relationships.

The main theme of BRI is realizing the Chinese dream. The main them of agenda 2063 is also realizing African renaissance. As Chinese president recurrently called that the Chinese dream is not a dream of realizing hegemony or winning the competition rather it is a dream that benefits both the Chinese people and the humanity. In tandem with the realizing the renaissance of Africa is not something wishing to dominate the world political and economic arena, rather a renaissance in which it works tirelessly for regaining the rightful positions that African need to get in the world stage.

From the above analysis, it surmounts to infer the fact that Chinese dream and African renaissance are not only complementary but also it could not be realized without each other's support and commitment. On the same line of thought, the BRI which is a brainchild of Chinese dream and Agenda 2063 which is a brainchild of African renaissance could only be realized when two parties work as partners who are visioning a world by which everyone benefits and gets its due.

\section{B. African Countries Participation in BRI Implementation}

Since the implementation of BRI, the participation of African countries in the initiative is many folds, which manifested in the infrastructural project construction, people to people relation, having bilateral relations and others.

African countries have participated in BRI has different formats [8]. It is possible to categorize the type of participation or coordination of African countries in the BRI into four which starts from softer to stronger ones. The first is expressing interest in deepening cooperation with China, which includes countries like Comoros, Djibouti, Madagascar, Sudan, Somalia, Seychelles, The second one is deepening bilateral cooperation with China under BRI, which signifies there is cooperation but shows an interest to deepen it(Algeria, Mauritania Mauritius, Morocco, Zambia, Tunisia,). The third is infrastructure cooperation which is explained by having some infrastructure projects (transport) in those African countries on the umbrella of BRI (Burundi, Guinea, Kenya, Mozambique, Rwanda, South Sudan, Uganda, Tanzania, and Zimbabwe). The fourth one is the signing of some institutional mechanism of BRI which is done only by (Ethiopia, Egypt and South Africa), which is the highest stage of cooperation on the BRI initiative. 
In the continental level, the Chinese government has made various pledges in recent years for Africa. For example, when the Chinese president visits Africa in 2015 has announced 10 major Africa-China Cooperation which is being implemented till 2018 [11]. Among those projects "offering 60 billion U.S. dollars of funding support, 5 billion dollars of additional capital for the China-Africa Development Fund, and a China-Africa production capacity cooperation fund with the initial capital of 10 billion dollars, train 200,000 technicians for African countries, and provide the continent with 40,000 training opportunities in China" are the main ones. Though we have seen these and others pledges and commitments, there is a lack in the side of Africa to fully leverage the full potential of the financial pledges and technical assistance pledges embedded in these partnerships. [10].

As people to people relationship is one BRI main priority areas, there are different activities carried on in Africa. The Johannesburg declaration states that "Strengthen people-topeople and cultural exchanges and cooperation between the two parties and, in particular, enhance exchanges in culture and art, education, sports, tourism, press and media, and between academia, think-tanks, the youth, women, trade unions and persons with disabilities, with a view to deepening the understanding and friendship between the peoples of China and Africa" [11].

Among this, the Africa-China young leaders forum, which is carried out under the auspices of FOCAC has been going well and this platform needs to be promoted well to integrate the future leaders of Africa and China.

\section{RECOMMENDATIONS FOR FUtURE ALIGNMENT OF AGENDA 2063 WITH BRI}

\section{A. Correcting Perception Problems}

The Perception of Africans on the Chinese visibility in Africa is twofold. One perceives China as another good alternative, understanding, a symbol of strength and a state to go with, and this perception is directed towards the state and the people. There is also a bleak side of perceiving China as the new colonizer, those who are only for money, who sabotage African natural resources; this perception is directed towards the Chinese business in Africa. The Chinese government needs to work more on ensuring that when Chinese Companies works in African soil they are like an ambassador of their country, their business profit is coupled with carrying out social responsibility and long-term business strategy.

\section{B. Working more on policy Coordination}

Coordination of policy between Africa and China is the bedrock for the smooth implementation of the BRI. This policy coordination needs to be handled in two steps. The first one is African countries need to solve policy coordination particularly including an equally implementing of regional or continental level projects in their national jurisdictions, as it has been one of the problems exhibited in Africa. Secondly, African countries need to come up in unison with some continental significance projects and galvanize resources from China through the BRI.

\section{Ensuring the realization of Commitments entered between China and Africa}

The commitment that has been entered between Africa and China in different areas needs to be realized. Africa as a continent and countries in Africa needs to mobilize their resource and capacity to ensure that the pledges of a Fund and technical assistance that has been committed by the Chinese state are collected and used for the purpose it has been planned for. On the same note, African as a continent and African countries needs to ensure that the Chinese business and personnel in their continent and countries have got a needed security protection.

\section{Further Research to Enhance Understanding about the BRI and Agenda 2063}

There is a meager of academic work and research about the interface between BRI and Agenda 2063. As both BRI and Agenda 2063 are grand documents which cover more than $1 / 3$ of world population and it is impossible to realize one without finding the link between the two conducting a detailed research and academic work and come up with common agenda is a timely endeavor.

\section{CONCLUSION}

The Chinese nation's experience and history with humiliation, semi-colonialism is somehow the same what African countries have experience. Not only has that resisting the colonialism and domination had been considered as a common element of China and Africa Countries.

China within the last four decades has uplifted about 700 million people from abject poverty by implementing different policies and strategies, among which the now in full swing is the BRI. Africa as a continent of 54 countries has made some progress with mixed results and the continental organ for these 54 countries has devised agenda 2063 to materialize the aspiration of African citizens within the next 40-50 years.

Hence, it is safe to conclude that, agenda 2063 and BRI are big documents devised to realize the dream of $1 / 3$ of world populations. These documents have been some common threads that push African countries and China to work to gather for the implementation of the same objectives. That is why working together between them has been shown in different areas, for example, infrastructure construction, people to people relations.

However to further realize the common agenda of African countries and China through BRI and Agenda 2063 both of them needs to cognizant of some issues, which includes solving the perception problem of Chinese business in Africa, enhance the people to people relationship, work on the policy coordination. By doing so the synergistic nature of both aspirations would be confidently realized.

\section{REFERENCES}

[1] X. Jinping, "Governance of China," 1st ed. Beijing: Foreign Language Press, 2014 
[2] X. Jinping "Speech at Forum on China and Africa Cooperation Johannesburg," 4 December 2015 online available from http://www.focac.org/eng/ltda/dwjbzjjhys_1/hyqk/t1321740.htm

[3] A.Cheng-Hin Lim, "Africa and China's 21st Century Maritime Silk Road," The Asia-Pacific Journal, Voulme13(11)(3), 2015, p.3

[4] L. Mohammed Marafa "Africa's Business and Development Relationship with China Seeking Moral and Capital Values of Last Economic Frontier.” Discussion Paper, Today Press AB, 2009, pp.6

[5] X. Jinping, "Governance Of China II," 1st Ed., Foreign Languages Press, Beijing, 2017 pp.546

[6] Anna Bruce-Lockhart, "China's $\$ 900$ billion New Silk Road. What you need to know", 26 June/2017World Economic Forum/ Can be accessed https://www.weforum.org/agenda/2017/06/china-new-silk-roadexplainer/

[7] Available from

https://www.aiib.org/en/about-aiib/governance/members-ofbank/index.htm

[8] China International Trade Institute. Industrial Cooperation between Countries along the Belt and Road, 2015.

[9] African Union Commission. Agenda 2063 Popular Version, Sep 2015, pp.1.

[10] Available at https://au.int/en/partnerships/africa_china

[11] Avilable at http://www.focac.org/eng/ltda/dwjbzjjhys_1/t1321742.htm 